\title{
В.А. Толкачева
}

\section{ВИРТУАЛЬНЫЙ МИР КУЛЬТУРНОЙ ПАМЯТИ: ФАНТАСТИКА ИЛИ ОБЬЕКТИВНАЯ РЕАЛЬНОСТЬ?}

\begin{abstract}
В статье рассматривается проблема перемещения культурной памяти из реального мира (как традиционной формы бытия) в виртуальное пространство. В XXI в. соотношение присутствия культурной памяти в реальной жизни и в виртуальном пространстве меняется в пользу последнего. Автор статьи задается вопросом, что привело к такому прочессу и есть ли будущее у культурной памяти в сети Интернет? Общество потребления возвело культурную память в ранг товара, который, чтобы стать востребованным, должен соответствовать современным требованиям. Самым перспективным направлением становятся междисциплинарные проекты, связываюшие культурную память с виртуалистикой.

Ключевые слова: культурная память, Интернет, виртуальное пространство.
\end{abstract}

Мемориальный бум конца 1980-х с громкими проектами «Войны памяти», «Травма социальной памяти», «Постпамять» и т.д. продолжается в XXI в. через социальные и культурные исследования не только в реальном, но и виртуальном пространстве. Причиной данного феномена можно считать наличие кардинальных сдвигов в ядре культурных ценностей. «Функционировавшая до сих пор картина мира, обладающая такими чертами, как антропоцентризм, универсальность, статичность, утверждавшая разум бытия и абсолютность мышления индивида, начинает распадаться, и внутри нее складывается прообраз новой картины мира, являющейся основой культурной парадигмы, который выходит за границы ориентации на ценности модернистской культуры» [1. С. 54] Современные исследования представляют собой обзоры состояния культурной памяти в различных областях, включая попытки генерировать новые традиции воспоминания, в том числе посредством сети Интернет. Антологии теоретических текстов, такие как The Collective Memory Reader (J.K. Olick и др. [2]), журнал Memory Studies, свидетельствуют о потребности сфокусировать общественное внимание на имеющихся и потенциальных возможностях использования культурной памяти при формировании социальной стабильности в обществе. Интернет предстает самым популярным, доступным, следовательно, эффективным ресурсом.

Диапазон тем и объекты современных исследований памяти фактически безграничны. Однако, в соответствии с научной позицией А. Конфино, несмотря на два десятилетия интенсивного исследования, дизайн концептуального комплекта инструментов для изучения культурной памяти до сих пор находится на «неоперившемся» этапе, потому что данные исследования носят «скорее практический, чем теоретический характер» [3. С. 81]. Объяснение данному феномену можно найти в современных потребностях общества. Наука в целом, а гуманитарная наука в особенности стала интересовать широкие слои общества, которое переносит специфические законы (принципы) 
и в научную сферу. Исследования заказываются не только государственными структурами, но и частными организациями. Свои коррективы вносит и Интернет с его безграничными возможностями.

\section{Междисциплинарность как предпосылка перемещения культурной памяти в виртуальное пространство}

Даже поверхностный взгляд на разнообразие терминов по исследованию памяти, начиная с Мориса Хальбвакса, во многом объясняет трудности, с которыми сталкиваются те, кто ищет концептуальную основу в данной области: коллективная память (mémoire collective), социальные рамки памяти (cadres sociaux), Мнемозина (Mnemosyne), искусство памяти (ars memoriae), места памяти (loci etimagines/lieux de mémoire/sites of memory), изобретенные традиции (invented traditions), миф (myth), наследие (heritage), поминание / поминовение (commemoration), культурная память (kulturelles Gedächtnis), коммуникативная память (communicative memory), память поколений (generationality), постпамять (postmemory). Многообразие терминов можно продолжать, что, в первую очередь, показывает, что культурная память не является объектом одной-единственной дисциплины.

Множество уникальных форм междисциплинарного сотрудничества уже создано. Самые внушительные исследования культурной памяти основаны на взаимодействии СМИ и истории культуры (J. Assmann; A. Assmann), истории и социологии (J.K. Olick), нейробиологии и социальной психологии (H. Welzer, H. Markowitsch), познавательной психологии и истории (D. Manier, W. Hirst), социальной психологии и лингвистики (G. Echterhoff). Самые перспективные проекты по исследованию культурной памяти связывают память и культуру, память и виртуалистику. Последняя отвечает современным требованиям потребителя памяти, моментально реагируя на его заказы и позволяя занимать активную позицию по отношению к воспоминаниям.

\section{В виртуальное пространство через культуру}

Исследования, связывающие память и культуру, активно финансируемые многими странами через систему грантов, направлены на сохранение памяти как приоритетной задачи сохранения государства. Здесь следует отметить, что культурная память более значима, чем историческая память, так как в отличие от последней она способствует объединению разных слоев общества и разных поколений. Этим и объясняется интерес именно к культурной памяти.

Согласно антропологическим и семиотическим исследованиям культура может быть рассмотрена как трехмерная структура, состоящая из социального (люди, общественные отношения, учреждения), материального (артефакты и СМИ) и умственного аспектов (культурно обусловленные способы мышления, менталитет) [4. С. 247]. Это различие не более чем эвристический инструмент. В действительности все три измерения включены в процесс создания культурных воспоминаний. Однако осознание трехмерности в исследовании культурной памяти позволяет делать вывод о наличии трансцендентных свойств культуры. В настоящее время интересы ученых распределены следующим образом: одни ученые изучают взаимодействие материальных и социальных явлений (например, мемориалы и политика памяти; E. Meyer); другие исследуют пересечения материальных и умственных явле- 
ний (например, менталитет; А. Confino); некоторые анализируют отношения познавательных и социальных явлений (как в диалоговом запоминании; D. Middleton, S.D. Brown). Интернет позволяет учесть трансцендентный характер культурной памяти, консолидировав ее трехмерность. В виртуальном пространстве все три аспекта находят наиболее полное отражение.

\section{Двухуровневая структура культурной памяти как отражение действительности}

Чтобы понять причины устремления культурной памяти в виртуальное пространство, можно воспользоваться структурой культурной памяти, предложенной А. Эррль и некоторыми другими учеными, которые выделяют два основных уровня культурной памяти: индивидуальный и коллективный.

Первый уровень касается биологической памяти. Это индивидуальная память, сформированная коллективными контекстами. Потребность в воспоминании исходит именно от субъекта. Коллективный контекст, обеспеченный в настоящее время медиа-ресурсами, помогает ему вспомнить прошлое и закодировать новый опыт. На первом этапе появляется потребность отдельного человека что-либо вспомнить. Однако сами воспоминания формируются под влиянием внешних факторов, под которыми понимаются и беседы с друзьями, и чтение книг, и посещение памятных мест. На данном уровне память используется в буквальном смысле, тогда как культурный признак является метонимией, обозначающей «социокультурные контексты и их влияние на память» [5. С. 5]. Данный уровень характерен для устной истории, социальной психологии и нейролингвистики.

Второй уровень культурной памяти, согласно А. Эррль, обращен к СМИ и различного рода учреждениям, которые конструируют общее прошлое. Память в данном случае используется метафорически. Речь не идет о памяти отдельного субъекта. Задачей данного уровня памяти является восстановление общего прошлого по заказу одного из участников общественных отношений. Общие воспоминания строятся на тех же принципах, что и память субъекта, манипулируя его потребностями. В истории культуры исследования относительно данного аспекта памяти проводили П. Нора, Я. Ассманн, А. Ассманн и др.

Оба уровня культурной памяти можно отличить друг от друга только в аналитическом плане. На практике они непрерывно взаимодействуют и существовать друг без друга не могут. Без подобного взаимодействия памятники, ритуалы, книги и т.д. - только мертвый материал, который не в состоянии оказать какое-либо влияние на развитие общества. Это же взаимодействие открыло путь к изучению некоторых специфических аспектов памяти на коллективном уровне, например, исследования травм, которые во многом и стали толчком к реализации виртуальных проектов памяти. К. Маркс утверждал, что все великие события и личности появляются дважды: первый раз в виде трагедии, второй раз в виде фарса [6. С. 12]. А. Ассманн предположила, что в современных условиях эта фраза может выглядеть иначе: «В истории все великие события и личности появляются дважды: первый раз как героизм (или триумф), второй раз как трагедия» [7. С. 87]. В качестве подтверждения своих слов она приводит примеры трагических событий на постсоветской территории и показывает различия в структуре культурной памяти ранее и теперь, 
так как в современном мире культурная память, по ее мнению, концентрируется не вокруг героических событий, а вокруг трагедии народа (травмы) [7. C. 81]. Изменения в содержании культурной памяти можно объяснить тем, что теория трагизма прошлого построена на более сильных эмоциях, человеческих переживаниях. Это дает дополнительные возможности для управления обществом.

А. Эткинд исследует трагические последствия советского прошлого [8]. Н.А. Колодий анализирует конфликты, связанные с культурной памятью (на примере реконструкции музея «Тюрьмы НКВД»), исследует степень участия памяти в формировании коллективной идентичности [9. С. 38]. Ее исследования посвящены «режиму памяти», или войне памяти [10. С. 244]. Исследования В. Канштайнера [11] акцентируют внимание на коллективной памяти о Холокосте в Германии. А. Винтер исследует травматическую память, связанную со Второй мировой войной. В книге «Память: фрагменты современной истории» анализируются события войны, описанные военными лидерами, врачами, солдатами. Ставится трудноразрешимая проблема баланса между воспоминаниями обычных участников войны и «ее организаторами», между врачебной этикой и узаконенной медицинской и психиатрической тиранией во время войны. Описываются поствоенные проблемы солдат ментального характера, которые испытывают и современные военные [12].

Самый эффективный способ эмоционального воздействия на общество при обсуждении трагических событий - это наглядность. С этой целью создаются специальные сайты, посвященные общественным травмам (ГУЛАГ, Холокост, Голодомор и т.д.).

\section{Взаимодействие памяти и виртуалистики как междисциплинарный проект}

Наименее изученной областью в междисциплинарном исследовании культурной памяти является взаимодействие памяти и виртуального пространства. Соотношение присутствия реального и виртуального миров в жизни современного человека быстро меняется в пользу виртуального. Полвека назад предсказания о развитии данного феномена казались фантастикой. Сегодня событие считается состоявшимся, если оно нашло свое отражение в сети Интернет. Для молодежи становится более естественным посетить мероприятие он-лайн, чем тратить время на реальное присутствие [13].

Культурная память как часть общественной жизни также перемещается в виртуальное пространство. Многие страны серьезно рассматривают Интернет как самый мощный инструмент для сохранения воспоминаний. По такому пути, например, пошел Гонконг.

Значительная часть работы над сохранением культурной памяти Гонконга выполняется университетами, системой образования в целом. Одним из выдающихся проектов стал веб-сайт «Hong Kong Memory» (http://www.hkmemory.hk/index.html). Это мультимедийный ресурс, который предоставляет открытый доступ к оцифрованным материалам по истории и культуре Гонконга. Материалы включают в себя текстовые отчеты, фотографии, плакаты, аудиозаписи, фильмы. Для работы над проектом организаторы привлекали известных ученых. Веб-сайт регулярно обновляется благо- 
даря активной деятельности преподавателей и студентов гонконгских университетов.

Этот ресурс содержит три больших раздела. Самым уникальным является раздел «Oral History» («Устная история»), который содержит более сотни аудиобесед с людьми различных возрастов, профессий и этнических групп. К сожалению, большинство записей представлено на кантонском диалекте китайского языка. Это объясняется возрастом многих пожилых интервьюеров, которые не говорят на английском языке [14].

Данный веб-сайт стал своеобразным ответом на программу ЮНЕСКО «Мировая память», которая призывает к сохранению ценных архивных фондов и коллекций библиотеки посредством оцифровки с целью защиты их от коллективной амнезии.

Российский виртуальный контент культурной памяти представлен сайтами, созданными при содействии ряда министерств (культуры, обороны, образования и науки и т.д.), а также по частной инициативе. Данные сайты посвящены, как правило, героическим страницам нашей истории либо грандиозным культурным событиям (http://www.may9.ru, http://mil.ru, http://podvignaroda.mil.ru/?\#tab=navHome и т.д.).

Также в виртуальное пространство перемещаются научные и популярные издания. Интернет позволяет увеличить читательскую аудиторию и эффективно работать над ее расширением. Необходимо отметить, что отдельные издательства становятся полностью виртуальными, отказываясь или изначально не имея печатного аналога. Наглядным примером таких издательств могут служить интернет-журналы Гефтер, Новое литературное обозрение и т.д. Отдельным направлением является сетевая литература, основной средой существования которой является Интернет.

Популярной платформой для виртуализации культурной памяти не только в России, но и по всему миру становятся социальные сети. Анализ контента Facebook и VKontakte, проведенный автором статьи, показал отличия в применении данных сетей российскими и европейскими пользователями. Европейцы более эмоциональны, открыты в свои постах, рассказывают о личном, комментируют даже малозначительные события. В целом используют социальные сети как дневник (находящийся в открытом доступе). Российские пользователи часто ограничиваются фотографиями с редкими комментариями. Основную часть контента составляют репосты социально значимой, рекламной, культурной и другой направленности. Действительно личная информация практически отсутствует, если не считать поздравлений с днем рождения или другим праздником. Таким образом, сохранение культурной памяти через социальные сети для России не является актуальным.

Сравнивая скорость погружения в виртуальное пространство российских и европейских пользователей сети Интернет, можно сделать вывод о том, что в Европе процессы перемещения культурной памяти в виртуальный мир протекают значительно быстрее. Объяснение данному феномену может заключаться в менталитете, во многом обусловленном средой обитания. В российской традиции сильна эмоциональная привязанность людей к своей территории, которая «зачастую формировалась через личный опыт познания» [15. С. 19] ранее необитаемой территории, например Сибири. «Преодоление трудностей, общее дело, адаптация к суровым условиям... выглядят как кон- 
структивный элемент в формировании сибирской идентичности» [15. С. 19]. Учитывая, что отдельные территории до сих пор остаются не до конца освоенными, эмоциональная привязанность к земле, к реальному миру у русских слишком сильна, особенно в местах, далеких от благ цивилизации. Однако процесс виртуализации как повседневной жизни (через социальные сети), так и культурной памяти (через специальные проекты) в России уже запущен.

В заключение необходимо отметить, что за последние годы культурная память кардинально меняет вектор своего развития, активно перемещаясь из реального мира в виртуальное пространство. Закономерность этого процесса отражена в данной статье. Интернет во всем его многообразии дает возможность для дальнейшего сохранения и развития культурной памяти. Более того, виртуальное пространство значительно расширяет горизонты культурной памяти, вовлекая в свою деятельность максимально широкую аудиторию.

\section{Лumepamypa}

1. Коробейникова Л.А., Забулионите А.-К.И. Реинтерпретация ценностей современной культуры // Вестник Томского государственного университета. Культурология и искусствоведение. 2017. № 27. С. 44-56.

2. Olick J.K. The Collective Memory Reader / eds. by Olick J.K., Vinitzky-Seroussi V., Levy D. Oxford University Press, USA, 2011. 497 p.

3. Confino A. Memory and the history of mentalities // Cultural Memory Studies: An International and Interdisciplinary Handbook / eds. by Erll A., Nunning A. Walter de Gruyter. Berlin, 2008. P. 77-84.

4. Posner R. What is Culture? Toward a Semiotic Explication of Anthropological Concepts // The Nature of Culture / ed. by W.A. Koch. Bochum : Brockmeyer, 1989. P. 240-295.

5. Erll A. Cultural Memory Studies: An Introduction // Cultural Memory Studies: An International and Interdisciplinary Handbook / eds. by Erll A., Nunning A. Walter de Gruyter. Berlin, 2008. P. 1-18.

6. Marx K. The Eighteenth Brumaire of Louis Bonaparte / ed. R. Bill. Published Online by Socialist Labor Party of America (www.slp.org). New York : Labor News, 2003. 120 p.

7. Assmann A. Theories of Cultural Memories and the Concept of "Afterlife". Published in: Afterlife of events: perspectives on mnemohistory / ed. by Tamm, Marek. Palgrave Macmillan. Basingstoke, 2015. P. 79-94.

8. Эткинд А. Двадцать лет спустя [Электронный ресурс] // Неприкосновенный запас. 2013. № 5(91). URL: http://magazines.russ.ru/nz/2013/5/9e.html (дата обращения: 31.03.2018).

9. Колодий Н.А. Режим культурной памяти // Ценности и смыслы. 2014. № 6 (34). С. 38-46.

10. Колодий Н.А. Лабиринт памяти - места памяти - война памяти: опыт истолкования // Вестник науки Сибири. 2013. № 1 (7). С. 240-245.

11. Kansteiner $W$. Finding Meaning in Memory: A Methodological Critique of Collective Memory Studies // History and Theory. 2002. № 41 (2). P. 179-197.

12. Winter A. Memory: Fragments of a Modern History. The University of Chicago, 2012. 319 p.

13. Loiko O., Mashkina O., Dryga S., Tolkacheva V., Zeremskaya Y. The Cyberspace in relation to the cultural memory // Innovation Management and Education Excellence Vision 2020: From Regional Development Sustainability to Global Economic Growth: Proceedings of the 27th International Business Information Management Association Conference. Milan, Italy, 2016. P. 68-73.

14. Толкачева B.A. Виртуальный мир культурной памяти: Гонконгский вариант // Международный научно-исследовательский журнал. 2016. №7 (49). С. 153-155.

15. Головнева E.B. «Чувство места» в Сибири: эмоциональный контент сибирской идентичности // Вестник Томского государственного университета. Культурология и искусствоведение. 2017. № 28. С. 17-26.

Tolkacheva Valentina A., Committee on the control, supervision and licensing in education (Tomsk, Russian Federation).

E-mail: tva-tkds@mail.ru

Tomsk State University Journal of Cultural Studies and Art History, 2018, 31, pp. 120-127. 
DOI: $10.17223 / 22220836 / 31 / 12$

THE VIRTUAL WORLD OF THE CULTURAL MEMORY: A FANTASY OR AN OBJECTIVE REALITY?

Keywords: cultural memory; Internet; virtual space.

The relevance of the researches that are devoted to the cultural memory is confirmed by a memorial boom which in the 21 st century is shown through the social and cultural projects not only in real, but also in virtual space. The most perspective projects in this field connect memory and culture, memory and virtual reality. The last one meets the modern requirements of the memory consumer, reacting to its orders and allowing to take an active position in relation to the reminiscences.

The researches connecting the memory and the culture which are actively financed by many countries through the system of grants are directed to preserving the memory as a priority target of the state preservation.

The least studied the area in a cross-disciplinary research of the cultural memory is an interaction of memory and virtual space. The ratio of presence of the real and virtual worlds in the modern human life quickly changes in favor of the virtual world. Many countries seriously consider the Internet as the most powerful tool for memory preservation. It is possible to give Hong Kong (http://www.hkmemory.hk/index.html) as an example of the global projects on memory virtualization as the answer to the program of UNESCO "World memory".

The Russian virtual content of the cultural memory is presented by the websites devoted to the heroic pages of our history or grandiose cultural events (http://www.may9.ru, etc.).

Scientific and popular publications (the online magazines Gefter, the New literary review) move to the virtual space as well. The Internet allows to increase reader's audience and to work effectively on its expansion.

Social networks become the popular platform for the cultural memory virtualization not only in Russia, but also worldwide. The analysis of the content of Facebook and VKontakte which is carried out by the author of the article has shown the difference in the application of networks data by the Russian and European users. Europeans are more emotional, open in their posts, tell about personal life, comment the even insignificant events. The Russian users are often limited to photos with rare comments. The main part of the content is made by reposts of socially important, advertizing, cultural and other orientation.

Thus, in recent years the cultural memory cardinally changes a vector of the development, actively moving from the real world to the virtual space. The Internet in all its variety gives the chance for the further preservation and development of the cultural memory. Moreover, the virtual space considerably expands the horizons of the cultural memory, involving the widest audience in the activity.

\section{References}

1. Korobeynikova, L.A. \& Zabulionite, A.-K.I. (2017) Reinterpretation of the values of modern culture. Vestnik Tomskogo gosudarstvennogo universiteta. Kul'turologiya i iskusstvovedeniye - Tomsk State University Journal of Cultural Studies and Art History. 27. pp. 44-56. (In Russian). DOI: $10.17223 / 22220836 / 27 / 5$

2. Olick, J.K. (2011) Schityvatel' kollektivnoy pamyati [The Collective Memory Reader]. Oxford University Press.

3. Confino, A. (2008) Memory and the history of mentalities. In: Erll, A. \& Nunning, A. (eds) Cultural Memory Studies: An International and Interdisciplinary Handbook. Berlin: Walter de Gruyter. pp. $77-84$.

4. Posner, R. (1989) What is Culture? Toward a Semiotic Explication of Anthropological Concepts. In: Koch, W.A. (ed.) The Nature of Culture. Bochum: Brockmeyer. pp. 240-295.

5. Erll, A. (2008) Cultural Memory Studies: An Introduction. In: Erll, A. \& Nunning, A. (eds) Cultural Memory Studies: An International and Interdisciplinary Handbook. Berlin: Walter de Gruyter. pp. 1-18.

6. Marx, K. (2003) The Eighteenth Brumaire of Louis Bonaparte. Published online by Socialist Labor Party of America (www.slp.org). New York Labor News..

7. Assmann, A. (2015) Theories of Cultural Memories and the Concept of "Afterlife". Basingstoke: Palgrave Macmillan. pp.79-94.

8. Etkind, A. (2013) Dvadtsat' let spustya [Twenty years later]. Neprikosnovennyy zapas. 5(91). [Online] Available from: http://magazines.russ.ru/nz/2013/5/9e.html. (Accessed: 31st March 2018). 
9. Kolodiy, N.A. (2014) Rezhim kul'turnoy pamyati [The mode of cultural memory]. Tsennosti $i$ smysly. 6(34). pp. 38-46.

10. Kolodiy, N.A. (2013) Labirint pamyati - mesta pamyati - voyna pamyati: opyt istolkovaniya [The labyrinth of memory - the place of memory - the war of memory: the experience of interpretation]. Vestnik nauki Sibiri - Siberian Journal of Science. 1(7) pp. 240-245.

11. Kansteiner, W. (2002) Finding Meaning in Memory: A Methodological Critique of Collective Memory Studies. History and Theory. 41(2). pp. 179-197. DOI: 10.1111/0018-2656.00198

12. Winter, A. (2012) Memory: Fragments of a Modern History. The University of Chicago.

13. Loiko, O., Mashkina, O., Dryga, S., Tolkacheva, V. \& Zeremskaya, Y. (2016) The Cyberspace in relation to the cultural memory. Innovation Management and Education Excellence Vision 2020: From Regional Development Sustainability to Global Economic Growth. Proc. of the 27th International Business Information Management Association Conference. Milan, Italy. pp. 68-73.

14. Tolkacheva, V.A. (2016) Virtual world of cultural memory: Hong Kong variant. Mezhdunarodnyy nauchno-issledovatel'skiy zhurnal - International Research Journal. 7(49). pp. 153155. (In Russian).

15. Golovneva, Ye.V. (2017) Place attachment in Siberia: the emotional component in the structure of Siberian identity. Vestnik Tomskogo gosudarstvennogo universiteta. Kul'turologiya $i$ iskusstvovedeniye - Tomsk State University Journal of Cultural Studies and Art History. 28. pp. 17-26. (In Russian). DOI: 10.17223/22220836/28/2 